\title{
GAMBARAN SIKAP TERHADAP KEBISINGAN PADA SISWA SMK NEGERI 2 MANADO
}

\author{
${ }^{1}$ Haidy Febrian Raintung \\ ${ }^{2}$ Steward K. Mengko \\ ${ }^{2}$ Julied Dehoop
}

\author{
${ }^{1}$ Kandidat Skrispi Fakultas Kedokteran Universitas Sam Ratulangi Manado \\ ${ }^{2}$ Bagian Telinga Hidung Tenggorok-Bedah Kepala Leher Fakultas Kedokteran \\ Universitas Sam Ratulangi Manado \\ Email: haidyrain@yahoo.com
}

\begin{abstract}
Hearing loss is the inability of a person's sense of hearing in listening range of sound that can still be heard by people with normal hearing. With the growing popularity of entertainment venues (discos, karaoke, music concerts, internet cafes, etc.) as well as the use of portable music player, leisure noise have become the primary source that causing increased incidence of adolescent noise induced hearing loss (NIHL). Attitudes towards noise needs to be assessed at a young age, this is because the attittude is the basis of behavior, and behavior (towards leisure noise) can affect the amount of noise exposure of each person. Chronicity of NIHL symptoms often make adolescent tends to ignore the serious long-term problem that can arise and not take steps to resolve it. Objective: The purpose of this study is to obtain data from students of Manado $2^{\text {nd }}$ Vocational Senior Secondary School concerning attitudes towards noise. Method: This research used descriptive observational with cross-sectional study. The subjects are students of Stone Concrete's majors in Manado $2^{\text {nd }}$ Vocational Senior Secondary Schoolthat have passed initial hearing screening. Result: Of the 20 respondents who willingly take part in this research, obtained 5 respondents (25\%) had negative attitude, 10 respondents (50\%) had neutral attitude, and 5 respondents (25\%) had positive attitude. From audiometric examination, obtained 4 respondents had a mild decreased in hearing threshold. Of the 4 respondents, 2 (50\%) of them had a neutral attitude and 2 other respondents (50\%) had positive attitude.

Conclusion: Respondents with positive attitude towards noise are vulnurable to hearing threshold changes caused by daily noise exposure.
\end{abstract}

Keywords: adolescent, hearing, noise, attitudes towards noise

Abstrak: Gangguan pendengaran merupakan ketidakmampuan indra pendengaran seseorang dalam mendengarkan rentang suara yang masih dapat didengar oleh orang dengan pendengaran normal. Semakin berkembangnya popularitas dari tempat-tempat hiburan (diskotik, karaoke, konser musik, warung internet, dan lain sebagainya) serta penggunaan pemutar musik portabel telah menjadi sumber peningkatan angka kejadian gangguan pendengaran akibat bising (GPAB) pada usia muda. Sikap terhadap kebisingan perlu dinilai pada usia muda, hal ini dikarenakan sikap merupakan dasar dalam berperilaku, dan perilaku (terhadap kebisingan sosial) dapat mempengaruhi derajat paparan bising masing-masing orang. Kronisitas dari gejala (GPAB) membuat kaum muda kurang menanggapi serius masalah-masalah jangka panjang yang dapat ditimbulkan, serta mengambil langkah untuk mengatasinya. Tujuan: Tujuan penelitian ini adalah untuk memperoleh data sikap terhadap kebisingan pada siswa sekolah menengah kejuruan (SMK) Negeri 2 Manado. Metode Penelitian:Penelitian ini merupakan penelitian deskriptif observasional dengan menggunakan metode cross-sectional. Subjek penelitian adalah siswa jurusan Teknik Konstruksi Batu Beton (TKBB) SMK Negeri 2 Manado yang sudah melewati screening pendengaran awal. Hasil: Dari 20 responden yang bersedia menjadi responden penelitian, didapatkan 5 responden (25\%) mempunyai sikap negatif, 10 responden 
(50\%) mempunyai sikap netral, dan 5 responden (25\%) mempunyai sikap positif. Dari pemeriksaan audiometrik, didapatkan 4 responden mengalami penurunan ambang dengar derajat ringan. Dari 4 responden tersebut, 2 (50\%) diantaranya mempunyai sikap netral dan 2 responden (50\%) mempunyai sikap positif.

Simpulan: Responden yang bersikap positif terhadap bising (pro-bising) rentan terhadap terjadinya perubahan ambang dengar yang akibatkan oleh paparan kebisingan sehari-hari.

Kata kunci: usia muda, pendengaran, bising, sikap terhadap kebisingan

Gangguan pendengaran merupakan ketidakmampuan indra pendengaran seseorang dalam mendengarkan rentang suara yang masih dapat didengar oleh orang dengan pendengaran normal. ${ }^{1}$ Data World Health Organization (WHO) tahun 2013 menyatakan bahwa lebih dari 360 juta penduduk dunia mengalami gangguan pendengaran. ${ }^{2}$ Lewat pelaksanaan program The Prevention of Noise-Induced Hearing Loss, WHO menyatakan bahwa gangguan pendengaran akibat bising (GPAB) merupakan tipe gangguan pendengaran yang paling banyak dialami masyarakat di seluruh dunia. ${ }^{3}$

Penyebab paling sering daripada GPAB adalah bising pekerjaan, terutama pekerjaan yang menggunakan mesin-mesin pabrik ataupun mesin-mesin elektronik. ${ }^{4-6}$ Namun semakin berkembangnya popularitas dari tempat-tempat hiburan (diskotik, karaoke, konser musik, warung internet, dan lain sebagainya) serta penggunaan pemutar musik portabel, dapat menjadi sumber peningkatan angka kejadian GPAB pada usia muda. ${ }^{7}$ Ditambah lagi, kronisitas dari gejala GPAB membuat kaum muda kurang menanggapi serius masalah-masalah jangka panjang yang dapat ditimbulkan, serta mengambil langkah untuk mengatasinya., ${ }^{8,9}$

Di Amerika, data NHANES (National Health and Nutrition Examination Survey) tahun 1984-2006, menyatakan prevalensi gangguan pendengaran anak usia 12-19 tahun meningkat dari $14,9 \%$ menjadi $19,5 \% .{ }^{10}$ Gilles et al melaporkan prevalensi tinitus (non-permanen maupun permanen) sebesar 74,7\% dan 18,3\% dari 3892 responden usia 12-19 di Jerman pada tahun 2012. ${ }^{9}$

Sikap terhadap kebisingan perlu dinilai pada usia muda, hal ini dikarenakan sikap menuntun perilaku kita sehingga kita akan bertindak sesuai dengan sikap yang kita ekspresikan, dimana jika dikaitkan dengan kebisingan, maka sikap seseorang akan mempengaruhi derajat paparan kebisingan orang tersebut. ${ }^{11}$ Dalam usaha untuk melakukan penilaian terhadap paparan kebisingan sosial, Widen et al menciptakan kuesioner untuk menelusuri sikap usia-usia muda dalam menghadapi kebisingan harian tersebut. Kuesioner ini diberi nama YANS (Youth Attitude to Noise Scale). ${ }^{12}$ Pada penelitian dengan menggunakan YANS, Gilles et al mendapatkan hanya 27,6\% (1074 orang) yang menganggap bising sebagai sesuatu yang harus sebisa mungkin dihindari, sisa 26,1\% responden (1015 orang) tersebut mempunyai sikap acuh terhadap bising, dan 45,1\% (1756 orang) mempunyai sikap netral. Walaupun begitu, didapatkan hanya $4,7 \%$ anak yang menggunakan pelindung telinga dari 1074 anak yang mempunyai sikap negatif terhadap bising. ${ }^{9}$

\section{METODE}

Penelitian ini menggunakan desain penelitian observasional deskriptif dengan pendekatan cross-sectional. Waktu pelaksanaan mulai dari bulan Desember 2013 sampai Januari 2014. Populasi dalam penelitian ini adalah siswa-siswa yang bersekolah di SMK Negeri 2 Manado. Kriteria inklusi yang digunakan dalam penelitian ini adalah persetujuan siswa untuk menjalani pemeriksaan audiometri, setelah melewati screening pemeriksaan kesehatan telinga luar. Jumlah sampel pada penelitian ini adalah 20 siswa jurusan Teknik Konstruksi Batu Beton.

\section{HASIL}

Dari 20 responden yang terpilih, 10 responden (50\%) berasal dari kelas XI dan 10 responden (50\%) lainnya berasal dari 
Raintung, Mengko, Dehoop; Gambaran Sikap terhadap Kebisingan...

kelas XII. Responden didominasi lebih banyak oleh siswa laki-laki dengan jumlah 18 siswa (90\%) dan sisanya 2 siswa perempuan (10\%).

Responden-responden yang terpilih kemudian diperiksa menggunakan audiometri nada murni. Dari pemeriksaan didapatkan 16 siswa (80\%) tidak mengalami perubahan ambang dengar dan 4 sisanya (20\%) didapatkan mengalami penurunan ambang dengar. Pemeriksaan audiometri nada murni menunjukkan penurunan ambang dengar derajat ringan pada 4 siswa.

Sebelum masing-masing responden diperiksa kualitas ambang dengarnya, responden diminta terlebih dahulu mengisi kuesioner untuk mengukur sikap terhadap kebisingan, kuesioner yang digunakan adalah kuesioner YANS (Youth Attitude to Noise Scale). Hasilnya didapatkan 5 siswa (25\%) mempunyai sikap negatif terhadap kebisingan, 10 siswa (50\%) mempunyai sikap netral, dan 5 siswa (25\%) lainnya bersikap positif terhadap bising.

Tabel 1. Gambaran rata-rata pengukuran skor YANS dan kuartil pembagian sikap

\begin{tabular}{lccccc}
\hline & Mean & SD & Negatif & Netral & Positif \\
\hline Faktor 1 & 2,46 & 0,69 & $1,00-2,14$ & $2,15-2,90$ & $2,89-5,00$ \\
Faktor 2 & 3,14 & 0,49 & $1,00-2,80$ & $2,81-3,56$ & $3,55-5,00$ \\
Faktor 3 & 2,58 & 0,81 & $1,00-2,00$ & $2,01-3,43$ & $3,44-5,00$ \\
Faktor 4 & 2,30 & 0,72 & $1,00-1,75$ & $1,76-2,57$ & $2,58-5,00$ \\
Total YANS & 2,64 & 0,52 & $1,00-2,22$ & $2,23-3,06$ & $3,07-5,00$ \\
\hline
\end{tabular}

dimana,

faktor 1 = sikap menyangkut kebisingan pada tempat-tempat rekreasi

faktor 2 = sikap menyangkut kemampuan berkonsentrasi di lingkungan bising

faktor 3 = sikap menyangkut kebisingan harian

faktor 4 = sikap menyangkut keinginan merubah lingkungan yang bising

Tabel 2. Tabulasi silang antara sikap terhadap kebisingan dan kelas responden

\begin{tabular}{llccclcl}
\hline & & \multicolumn{3}{c}{ Kelas } & \multicolumn{3}{c}{ Total } \\
\cline { 3 - 6 } & & \multicolumn{2}{c}{ XI } & \multicolumn{3}{c}{ XII } & \\
Sikap & Negatif & 3 & Persen & N & Persen & $\mathrm{n}$ & Persen \\
terhadap & Netral & 3 & $30 \%$ & 2 & $40 \%$ & 5 & $100 \%$ \\
kebisingan & Positif & 4 & $80 \%$ & 7 & $70 \%$ & 10 & $100 \%$ \\
\hline
\end{tabular}

Tabulasi silang antara sikap terhadap kebisingan dengan kelas menunjukkan siswa-siswa yang bersikap negatif dan positif lebih banyak berada pada kelas XI dengan persentase masing-masing $60 \%$ dan $80 \%$. Siswa dengan sikap netral lebih banyak didapatkan pada kelas XII dengan persentase $70 \%$.

Tabulasi silang antara sikap terhadap kebisingan dengan jenis kelamin menunjukkan kedua siswa perempuan yang menjadi responden penelitian masing-masing mempunyai sikap negatif dan sikap netral. Mayoritas data tersebar pada responden
Tabel 3. Rata-rata dan deviasi standar dari nilai total serta faktor-faktor YANS dari masingmasing kelas

\begin{tabular}{cccc}
\hline Faktor & Kelas & Mean & SD \\
\hline \multirow{2}{*}{ Faktor 1 } & XI & 2,32 & 0,69 \\
& XII & 2,60 & 0,70 \\
\multirow{2}{*}{ Faktor 2 } & XI & 3,20 & 0,54 \\
& XII & 3,08 & 0,47 \\
\multirow{2}{*}{ Faktor 3 } & XI & 2,50 & 0,77 \\
& XII & 2,67 & 0,88 \\
\multirow{2}{*}{ Faktor 4 } & XI & 2,33 & 0,80 \\
& XII & 2,27 & 0,66 \\
\multirow{2}{*}{ Total } & XI & 2,59 & 0,54 \\
& XII & 2,69 & 0,52 \\
\hline
\end{tabular}


Tabel 4. Tabulasi silang antara sikap terhadap kebisingan dan jenis kelamin responden

\begin{tabular}{llcccccc}
\hline & & \multicolumn{4}{c}{ Jenis Kelamin } & \multicolumn{2}{c}{ Total } \\
\cline { 3 - 5 } & & \multicolumn{2}{c}{ Laki-Laki } & \multicolumn{2}{c}{ Perempuan } & & \\
Sikap & Negatif & 4 & Persen & $\mathrm{N}$ & Persen & $\mathrm{n}$ & Persen \\
terhadap & Netral & $90 \%$ & 1 & $20 \%$ & 5 & $100 \%$ \\
kebisingan & Positif & 5 & $90 \%$ & 1 & $10 \%$ & 10 & $100 \%$ \\
\hline
\end{tabular}

Tabel 5. Tabulasi silang antara sikap terhadap kebisingan dan hasil pengukuran ambang dengar

\begin{tabular}{llcccc}
\hline & & \multicolumn{3}{c}{ Ambang dengar } \\
\cline { 3 - 6 } & & \multicolumn{2}{c}{ Menurun } & \multicolumn{2}{c}{ Normal } \\
Sikap & Negatif & $\mathrm{n}$ & Persen & $\mathrm{N}$ & Persen \\
terhadap & Netral & 0 & $0 \%$ & 5 & $31,25 \%$ \\
kebisingan & Positif & 2 & $50 \%$ & 8 & $50,00 \%$ \\
& Total & 2 & $50 \%$ & 3 & $18,75 \%$ \\
& & 4 & $100 \%$ & 16 & $100 \%$ \\
\hline
\end{tabular}

Tabel 6. Hasil skoring YANS dan hasil masing-masing faktor pada siswa-siswa yang mengalami penurunan ambang dengar

\begin{tabular}{lccccc}
\hline No & Faktor $\mathbf{1}$ & Faktor $\mathbf{2}$ & Faktor $\mathbf{3}$ & Faktor $\mathbf{4}$ & Total \\
\hline $\mathbf{1 .}$ & 3,57 & 3,80 & 3,00 & 2,33 & 3,32 \\
$\mathbf{2 .}$ & 2,00 & 3,00 & 3,60 & 3,25 & 3,32 \\
$\mathbf{3 .}$ & 2,57 & 3,20 & 2,50 & 2,67 & 2,74 \\
$\mathbf{4 .}$ & 1,86 & 3,40 & 3,50 & 1,67 & 2,58 \\
\hline
\end{tabular}

laki-laki. Tidak dilakukan lagi perbandingan lebih lanjut dikarenakan jumlah responden perempuan yang sedikit jika dibandingkan dengan jumlah responden laki-laki.

Tabulasi silang antara hasil gambaran ambang dengar dan sikap terhadap kebisingan menunjukkan siswa-siswa yang mempunyai sikap negatif tidak mengalami penurunan ambang dengar. Siswa-siswa (4 siswa) yang mengalami perubahan ambang dengar 2 (50\%) diantaranya mempunyai sikap netral dan 2 lainnya (50\%) mempunyai sikap positif.

\section{BAHASAN}

Dari hasil pemeriksaan sikap dalam menghadapi kebisingan dengan menggunakan kuesioner YANS yang dilakukan pada 20 siswa SMK Negeri 2 Manado jurusan Teknik Konstruksi Batu Beton (TKBB), didapatkan 25\% mempunyai sikap negatif (anti-bising), 50\% diantaranya bersikap netral, dan $25 \%$ sisanya mempunyai sikap positif (pro-bising). Hasil serupa juga didapatkan pada penelitian yang dilakukan oleh Gilles et al, dimana dari 3991 responden didapatkan 27,6\% mempunyai tergolong dalam sikap negatif, 26,1\% tergolong dalam sikap positif, dan 46,3\% sisanya pada sikap netral. ${ }^{9}$ Hasil ini harusnya akan selalu bersifat konstan (walau dapat terdapat variasi) pada setiap penelitian serupa. Hal ini disebabkan karena penentuan penggolongan sikap dinilai dengan menggunakan metode kuartil, dimana penilaian dilakukan setelah seluruh hasil skor kuesioner YANS masing-masing respoden didapatkan, lalu skor-skor yang terkumpul dibagi dalam 3 kelompok, yaitu 25\% nilai jumlah skor terendah pada kelompok negatif, 25\% jumlah skor tertinggi pada kelompok positif, dan sisa $50 \%$ skor pada kelompok netral. 
Hasil rata-rata skor kuesioner yang didapatkan pada penelitian ini adalah 2,63 $(\mathrm{SD}=0,52)$ dari 20 responden. Hasil ini lebih rendah jika dibandingkan dengan hasil rata-rata kuesioner yang didapatkan pada penelitian lain, dimana Widen et al mendapatkan rata-rata skor 3,18 $(\mathrm{SD}=0,51)$ dari 258 responden, rata-rata skor 2,80 (SD $=1,31)$ dari 245 responden pada penelitian Zocoli et al, dan rata-rata skor 3,10 (SD = 0,4) dari 3991 responden pada penelitian Gilles et al. ${ }^{9,13,14}$ Dari hasil ini dapat ditarik kesimpulan bahwa usia muda yang menjadi responden pada penelitian ini, yang terutama adalah siswa-siswa SMK Negeri 2 Manado jurusan TKBB, sebagian besar mempunyai sikap atau pandangan yang lebih baik dalam menyikapi kebisingan. Faktor-faktor yang mempengaruhi rendahnya hasil adalah faktor 1, 3, dan 4 yang berada di bawah nilai rata-rata. Hasil menyarankan bahwa kebanyakan responden penelitian cenderung mengarah pada sikap kurang mentolerir kebisingan pada tempat-tempat hiburan dan menyenangi lingkungan suara yang nyaman bagi mereka. Namun nampaknya kebisingan yang dihadapi sehari-hari, seperti bising lalu-lintas, bising dari media elektronik, dan lain-lain masih kurang diperhatikan.

Dari hasil pembagian sikap yang didapatkan dari kuesioner YANS, nampak responden yang tergolong dalam sikap negatif dan positif berada lebih banyak pada kelas XI (masing-masing 60\% dan 80\%). Sedangkan kelompok netral lebih banyak didapatkan pada kelas XII (70\%). Hasil yang didapatkan memperlihatkan bahwa responden kelas XI memiliki variasi sikap yang lebih tersebar rata dibandingkan pada kelas XII, dimana kebanyakan sikap responden kelas XII terkumpul pada golongan netral. Apa yang menyebabkan perbedaan polaritas sikap pada kedua kelas tersebut tidak dapat diketahui, dikarenakan satu-satunya variabel yang membedakan kedua grup tersebut hanyalah perbedaan umur yang kurang lebih 1 tahun, dimana peneliti merasa perbedaan tersebut tidak cukup signifikan sebagai faktor pengaruh yang kuat. Kemungkinan besar hasil muncul lebih diakibatkan oleh peluang, dikarenakan sedikitnya jumlah sampel yang ada. Selanjutnya, rencana awal peneliti untuk membandingkan rata-rata skor YANS antara responden laki-laki dan perempuan tidak dapat dijalankan lebih lanjut, hal ini dikarenakan kurangnya responden perempuan yang didapatkan sehingga perbandingan yang akan dilakukan dirasakan tidak memiliki makna.

Selain penilaian sikap terhadap kebisingan, dilakukan juga penilaian audiometrik untuk mencari tahu gambaran ambang dengar masing-masing responden, hal ini dilakukan untuk menelusuri lebih lanjut hipotesis dari Widen et al yang menyatakan bahwa sikap didapatkan tidak berkorelasi langsung dengan perubahan ambang dengar, namun cenderung lebih memiliki hubungan dengan kesadaran atau perubahan sikap masing-masing responden sebelum atau sesudah menyadari gejalagejala gangguan pendengaran yang mereka dapatkan. ${ }^{13}$ Pemeriksaan dilakukan dengan menggunakan audiometri nada murni, dimana dari 20 responden yang diperiksa, 80\% diantaranya (16 responden) tidak didapatkan mengalami perubahan ambang dengar, dan $20 \%$ (4 responden) mengalami penurunan ambang dengar derajat ringan. Hasil didapatkan dengan menggunakan standar WHO, dimana hasil normal mempunyai ambang dengar berkisar pada 0$25 \mathrm{~dB}$, dan penurunan ambang dengar derajat ringan berkisar pada $26-40 \mathrm{~dB} .{ }^{15}$

Lewat analisa tabulasi silang antara sikap dan ambang dengar, diketahui 4 orang yang mengalami penurunan ambang dengar tersebut $50 \%$ diantaranya (2 responden) tergolong pada sikap netral, dan 50\% sisanya (2 responden) tergolong pada sikap positif. Mengesampingkan yang mempunyai sikap netral, nampak bahwa dua responden yang mengalami perubahan ambang dengar mempunyai sikap positif dengan skor YANS yang cukup tinggi. Hasil ini dapat menyarankan adanya korelasi positif antara hasil kuesioner dan penurunan ambang dengar, yang tentu saja berlawanan dengan hasil yang didapatkan oleh Widen et al. Hanya saja mengingat sedikitnya jumlah data yang didapatkan, sehingga ada 
kemungkinan hasil yang didapatkan hanya hasil dari peluang saja. Menarik untuk diperhatikan bahwa hasil pengukuran kuesioner dilakukan sebelum masingmasing responden mengetahui hasil pengukuran ambang dengar mereka. Ada kemungkinan jika pengisian kuesioner dilakukan lagi kedepannya oleh respondenresponden yang mengalami penurunan ambang dengar tersebut, hasilnya dapat berbeda dari hasil yang didapatkan, dengan harapan akan terjadinya penurunan yang substansial pada skor masing-masing responden, setelah mereka mengetahui telah terjadinya penurunan kemampuan dengar pada diri mereka.

Peneliti menyadari bahwa penelitian ini masih memiliki banyak keterbatasan dan kekurangan, beberapa diantaranya adalah kurangnya jumlah sampel penelitian, terutama untuk penelitian yang menggunakan alat ukur subjektif, sehingga timbul kecurigaan hasil yang didapatkan merupakan hasil yang muncul karena peluang saja. Variabel-variabel penelitian dalam mencari tahu gangguan pendengaran akibat kebisingan rekreasional juga masih terbatas, dimana dalam penelitian ini hanya dipergunakan penelusuran sikap dengan kuesioner YANS, dimana peneliti menyarankan kedepannya untuk menelusuri juga tindakan responden terhadap kebisingan, seperti contoh penelusuran penggunaan musik yang keras. Selain itu, dapat juga digunakan standar pengukuran dengan menggunakan kuesioner lainnya.

\section{SIMPULAN}

Responden yang bersikap positif terhadap bising (pro-bising) rentan terhadap terjadinya perubahan ambang dengar yang akibatkan oleh kebisingan.

\section{DAFTAR PUSTAKA}

1. Mosby's Medical Dictionary [Internet]. 8th ed. St. Louis: Mosby; 2009. Hearing Loss. [cited 2013 Oct 4]. Available from: http://medicaldictionary.thefreedictionary.co $\mathrm{m} /$

2. Fact sheet: Deafness and hearing loss
[Internet]. World Health Organization; 2013 February [cited 2013 Oct 4]. Available from:http://www.who.int/mediacentre/factsh eets/fs300/en/

3. Smith AW. The World Health Organisation and the prevention of deafness and hexaring impairment caused by noise. Noise Health [serial online] 1998 [cited 2013 Oct 4];1:612. Available from: http://www.noisean dhealth.org/text.asp?1998/1/1/6/31782

4. Nelson DI, Nelson RY, Concha-Barrientos $\mathrm{M}$, Fingerhut $\mathrm{M}$. The global burden of occupational noise-induced hearing loss. Am J Ind Med [Internet]. 2005 Dec [cited 2013 Oct 4]; 48(6):446-58. Available from: http://onlinelibrary.wiley.com/doi/10.1002/a jim.20223/abstract

5. Harmadji S, Kabullah H. Noise induced hearing loss in steel factory workers. FolicaMedicaIndonesiana [Internet]. 2004 [cited 2013 Oct 4]; 40(4):171-4. Available from: journal.unair.ac.id/filerPDF/FMI-404-04.pdf

6. Tjan H, Lintong F, Supit W. Efekbisingmesinelektronikaterhadapganggu anfungsipendengaranpadapekerja di kecamatanSariokota Manado, Sulawesi Utara. e-BioMedic [Internet]. 2013 [cited 2013 Oct 4]; 1(1):34-9. Available from: http://ejournal.unsrat.ac.id/index.php/ebiom edik/article/download/1158/934

7. Zhao F, French D, Manchaiah VKC, Liang $\mathrm{M}$, Price SM. Music exposure and hearing health education: A review of knowledge, attitude, and behaviour in adolescents and young adults. Health Educ J [Internet]. 2012 Nov [cited 2013 Oct 4]; 71(6):709-24. Available from: http:/hej.sagepub.com/ content/71/6/709.abstract

8. Bogoch II, House RA, Kudla I. Perceptions about hearing protection and noise-induced hearing loss of attendees of rock concerts. Can J Public Health [Internet]. 2005 JanFeb;96(1):69-72. Available from: http:// www.ncbi.nlm.nih.gov/pubmed/15682701

9. Gilles A, Van Hal G, De Ridder D, Wouters K, Van de Heyning P (2013) Epidemiology of Noise-Induced Tinnitus and the Attitudes and Beliefs towards Noise and Hearing Protection in Adolescents. PLoS ONE 8(7): e70297. doi:10.1371/journal.pone.0070297

10. Shargorodsky J, Curhan SG, Curhan GC, Eavey R. Change in prevalence of hearing loss in US adolescents. JAMA. 2010;304(7):772-778. doi:10.1001/jama. 2010.1124. Available from: 
Raintung, Mengko, Dehoop; Gambaran Sikap terhadap Kebisingan...

http://jama.jamanetwork.com/article.aspx?ar ticleid=186427\#ref-joc05105-3

11. Sunaryo. Psikologiuntukkeperawatan. Jakarta: EGC; 2004.

12. Olsen Widen S E, Erlandsson S I. Selfreported tinnitus and noise sensitivity among adolescents in Sweden. Noise Health [serial online] 2004 [cited 2014 Apr 24];7:29-40. Available from: http://www.noiseandhealth.org/text.asp?200 4/7/25/29/31649

13. Widen SE, Holmes AE, Johnson T, Bohlin $\mathrm{M}$, Erlandsson SI. Hearing, use of hearing protection, and attitudes towards noise among young American adults. International Journal of Audiology 2009; 48:537545.
Available from: faculty.elmira.edu/tjohnson/ hearing_attitudes.pdf

14. Zocoli AMF, Morata TC, Marques JM. Youth Attitude to Noisce Scale (YANS) questionnaire adaptation into Brazillian Portuguese. Braz. J Otolaringology 2009;75(4):485-92. Available from: http://www.scielo.br/pdf/bjorl/v75n4/v75n4 a03.pdf

15. Hendarmin H, Bashiruddin J. Gangguan pendengaran dan kelainan telinga. In: Soepardi EA, Iskandar N, Bashiruddin J, Restuti RD. Buku ajar ilmu kesehatan telinga hidung tenggorok kepala \& leher. 6th ed. Jakarta: Balai Penerbit FKUI; 2007. 